Neves, R.M.S.; Lima, M.A.V. Tucorin: turismo comunitário no Baixo Rio Negro (AM). Anais do IX Congresso Nacional de Ecoturismo e do V Encontro Interdisciplinar de Turismo em Unidades de Conservação. Revista Brasileira de Ecoturismo, São Paulo, v.6, n.4, nov-2013, p.221.

\title{
Roteiro Tucorin: turismo comunitário no Baixo Rio Negro (AM)
}

\author{
Ruth Maria de Souza Neves, ${ }^{*}$ Marco Antonio Vaz de Lima* \\ *Organização Não Governamental Nymuendaju, Manaus, AM, Brasil. \\ E-mail: ruthturismologa@hotmail.com
}

Esta proposta tem como base o conceito de Desenvolvimento Sustentável no limiar dos novos paradigmas ambientais, que estabelece a busca da sustentabilidade através da autonomia do capital humano e de sua participação efetiva no controle, fiscalização e exploração racional dos recursos naturais existentes, ainda mais quando nos referimos ao bioma amazônico e principalmente em se tratando de áreas protegidas. Por isso a escolha de atividades do turismo no segmento do ecoturismo surge como uma alternativa viável para o desenvolvimento de trabalho, renda, qualidade de vida, através do envolvimento e participação das comunidades. O Roteiro de Turismo Comunitário no Baixo Rio Negro tem como objetivo valorizar o cotidiano dos ribeirinhos, por meio de uma interação justa e solidária entre visitantes e comunitários. A necessidade da implementação de um roteiro de turismo comunitário na região do baixo Rio Negro, onde o turismo convencional ocorre pelo menos duas décadas, fez algumas instituições governamentais e não governamentais, juntamente com as comunidades se unirem, para a construção de uma estratégia que os comunitários fossem os protagonistas, fazendo a gestão em praticamente todas as fases do processo, por exemplo, o turista paga pelos serviços diretamente aos comunitários. A ideia de consolidar um roteiro comunitário no Rio Negro surgiu a partir do edital "Talentos do Brasil" do Ministério do Turismo que resultou em uma abertura para a inclusão das comunidades, que hoje atuam no Roteiro Tucorin. Com a criação da Central de Turismo Comunitário da Amazônia (CTCA), o roteiro passou a ser divulgado em site. A metodologia para capacitação das comunidades foi à participativa, e com ajuda dos comunitários foi elaborado um roteiro turístico para cada comunidade. As instituições, Nymuendaju e o Instituto de Pesquisas Ecológicas (IPÊ), atuam de forma a dar apoio e aporte técnico para os comunitários inseridos no roteiro, desenvolvendo oficinas e reuniões para avaliação e fortalecimento das ações, considerando temas relevantes para a atividade, como: Turismo de Base Comunitária em nossa comunidade; visões sobre o turismo local atual; receptividade ao turista; planejamento participativo; levantamentos de atrativos na comunidade; demanda turística e oferta turística; hospedagem; alimentação; transporte; precificação de serviços e produtos comunitários: métodos de divulgação (marketing). Alguns questionamentos levantados em reuniões com participação dos comunitários deixa claro que ainda existem muitas dificuldades a serem superadas, tais como: melhorar a infraestrutura (energia, saneamento básico, comunicação, transporte entre outros); tornar possível a efetivação de políticas públicas (saúde, educação, segurança, infraestrutura); capacitar os comunitários (idiomas, recepção ao turista, culinária, primeiros socorros, associativismo) e viabilizar a participação de comunitários em eventos na temática de TBC e intercâmbios. Embora se compreenda tais questionamentos, o projeto justifica-se pelos resultados significativos trazidos para as comunidades, como: mudança no comportamento em relação às práticas ambientais; implementação de projetos sustentáveis, a partir do uso dos recursos naturais (confecção de balas e doces com polpa de frutas); aperfeiçoamento e burilamento das técnicas artesanais e escoamento desta produção); a valorização da cultura local pelos próprios comunitários, elevando assim o seu sentimento de pertencimento. Como resultado espera-se a melhoria do turismo local e dos serviços oferecidos com foco na sustentabilidade dessas comunidades.

PALAVRAS-CHAVE: Turismo Comunitário; Roteirização Turística; Planejamento Participativo; Desenvolvimento Sustentável. 
Neves, R.M.S.; Lima, M.A.V. Tucorin: Community tourism in the Lower Rio Negro (AM, Brazil). Anais do IX Congresso Nacional de Ecoturismo e do V Encontro Interdisciplinar de Turismo em Unidades de Conservação. Revista Brasileira de Ecoturismo, São Paulo, v.6, n.4, nov-2013, p.222.

\title{
Roteiro Tucorin: Community tourism in the Lower Rio Negro (AM, Brazil)
}

\author{
Ruth Maria de Souza Neves, * Marco Antonio Vaz de Lima* \\ *Organização Não Governamental Nymuendaju, Manaus, AM, Brasil. \\ E-mail: ruthturismologa@hotmail.com
}

This proposal is based on the concept of Sustainable Development at the threshold of the new environmental paradigm, establishing the pursuit of sustainability through the autonomy of human capital and its effective participation in the control, supervision and rational exploitation of natural resources, especially when the refer to the Amazon biome and especially in the case of protected areas. Therefore the choice of tourism activities in the ecotourism segment emerges as a viable alternative to the development of work, income, quality of life, through the involvement and participation of the communities. The path Community Tourism in the Lower Rio Negro aims to enhance the daily lives of the locals, through a fair and supportive interaction between visitors and community. The need to implement a roadmap for the tourism community of the Lower Rio Negro, where the conventional tourism occurs at least two decades, made some governmental and non-governmental organizations, together with the communities to come together, to build a strategy that Community were the protagonists, making the management in virtually all phases of the process, for example, the tourist pays for services directly to community residents. The idea of consolidating an path in Rio Negro emerged from the edict "Talents of Brazil" from the Ministry of Tourism has resulted in an opening for the inclusion of communities who currently work in the Roadmap Tucorin. With the creation of the Central Community Tourism Amazon (CTCA), guide has to be disclosed on the website of CTCA and started thes receipt of the first groups. Some training was conducted with the objective of participatory building a tour for each community, aimed at sustainable development of the same. The Institutions, and Nymuendaju Ecological Research Institute - IPE - act in order to make a technical contribution to the community residents, inserted in the process, developing workshops and meetings for evaluation and strengthening actions, considering issues relevant to the activity, such as : Unit Tourism Community our Community ; Views on current local tourism , the tourist receptivity ; participatory planning ; surveys attractive community ; tourist demand and tourism, lodging, food, transport, pricing of services and products shall : methods of dissemination (marketing). Some questions raised in meetings with participation of the community makes it clear that there are still many difficulties to be overcome, such as improving infrastructure (energy, sanitation, communication, transportation and others) ; Making possible the effectiveness of public policies (health, education , security, infrastructure) ; Empowering Community (languages, the tourist reception, cooking, first aid , associations) ; Facilitate the participation of community events on the theme of TBC and exchanges. Although it is understood such questions, the project is justified by the significant results brought to communities, such as: behavior change in relation to environmental practices; implementing sustainable projects, from natural resource use (manufacture of candies and sweets with pulp fruit); improvement and chipping of craft techniques and flow of this production), the development of local culture by the community, thus increasing their sense of belong in the community. As a result it is expected to improve local tourism and services offered with a focus on sustainability of these communities.

KEYWORDS: Community Tourism; Tourist Routing; Participatory Planning; Sustainable Development. 